\title{
Peridotite, kimberlite, and carbonatite explained in the system $\mathrm{CaO}-\mathrm{MgO}-\mathrm{SiO}_{2}-\mathrm{CO}_{2}$
}

\author{
Peter J. Wyllie \\ Department of Geophysical Sciences \\ University of Chicago \\ Chicago, Illinois 60637 \\ Wuu-Liang Huang \\ Department of Geology \\ National Taiwan University \\ Taipei, Taiwan
}

\begin{abstract}
The key to the origin of carbonatite and kimberlite lies in the system $\mathrm{CaO}$. $\mathrm{MgO}-\mathrm{SiO}_{2}-\mathrm{CO}_{2}$. Increase in pressure causes a carbonation reaction in the peridotite assemblage as follows: forsterite + clinopyroxene $+\mathrm{CO}_{2} \rightleftharpoons$ orthopyroxene + carbonate ( $\mathrm{Ca}: \mathrm{Mg}:: 70: 30)$. This reaction passes through $15 \mathrm{~kb}-960^{\circ} \mathrm{C}$ with slope $45 \mathrm{~b} /{ }^{\circ} \mathrm{C}$ and terminates at an invariant point near $25 \mathrm{~kb}-1200^{\circ} \mathrm{C}$, where melting begins. This intersection of the carbonation reaction with the solidus introduces primary carbonate minerals alongside peridotite minerals on the liquidus surface. At $20 \mathrm{~kb}$ the melting temperature of the peridotite assemblage Fo $+\mathrm{Opx}+\mathrm{Cpx}$ is lowered $75^{\circ} \mathrm{C}$ by solution of about 5 wt percent $\mathrm{CO}_{2}$. The liquid corresponds to undersilicated basic magma. Stabilization of carbonate increases $\mathrm{CO}_{2}$ solubility in the liquid, and above $25 \mathrm{~kb}$ the liquidus reaction involving $\mathrm{Fo}+\mathrm{Opx}+\mathrm{Cpx}+\mathrm{CO}_{2}$ sweeps down through $400^{\circ} \mathrm{C}$ via a pressure maximum

at $32 \mathrm{~kb}$ to meet the invariant point at $25 \mathrm{~kb}$. The peridotite solidus curve at higher pressures involves fusion of silicates and carbonates, producing a carbonatitic liquid with more than $45 \mathrm{wt}$ percent $\mathrm{CO}_{2}$. Progressive fusion produces a kimberlitic liquid. There is an intricate series of reactions between $25 \mathrm{~kb}$ and $35 \mathrm{~kb}$ involving changes in silicate and carbonate phase fields on the $\mathrm{CO}_{2}$ saturated liquidus surface. Fractional crystallization of $\mathrm{CO}_{2}$-bearing undersilicated basic magmas at most pressures yields residual kimberlite and carbonatite. Kimberlite and carbonatite magmas rising from the asthenosphere evolve $\mathrm{CO}_{2}$ as they reach a reaction boundary at a depth of about 100 to $80 \mathrm{~km}$. This contributes to their explosive eruption. Free $\mathrm{CO}_{2}$ cannot coexist with subsolidus mantle peridotite with normal temperature distributions. $\mathrm{CO}_{2}$ appears to be as effective as $\mathrm{H}_{2} \mathrm{O}$ in causing incipient melting in the asthenosphere.
\end{abstract}




\section{INTRODUCTION}

There is currently much interest in the effects of $\mathrm{CO}_{2}$ and $\mathrm{H}_{2} \mathrm{O}$ on magmatic processes in the mantle. Experiments with realistic bulk compositions, involving very small proportions of the volatile components, produce only trace amounts of liquid, which are difficult to study in detail. The relationships of the liquids with $\mathrm{CO}_{2}$ to the mantle peridotite minerals-forsterite, orthopyroxene, and clinopyroxene-can be examined in detail in the carbonate-rich part of the system $\mathrm{CaO}-\mathrm{MgO}-\mathrm{SiO}_{2}-\mathrm{CO}_{2}$. The key to the petrogenetic links between carbonatite, kimberlite, and peridotite lies in the intersection of a decarbonation reaction with the solidus curve. Free $\mathrm{CO}_{2}$ cannot normally exist in the mantle; it reacts with peridotite to produce a carbonate solid solution with composition about 7:3::Ca:Mg. Carbonatite and kimberlite are produced as primary magmas from carbonated mantle peridotite only at depths greater than $80 \mathrm{~km}$ and at moderate temperatures.

\section{DECARBONATION REACTIONS}

Bowen's (1940) petrogenetic grid was based initially on a series of decarbonation reactions in the system $\mathrm{CaO}-\mathrm{MgO}-\mathrm{SiO}_{2}-\mathrm{CO}_{2}$, with starting assemblages involving mixtures of calcite, dolomite, magnesite, and quartz, representing siliceous dolomites. The successive reactions introduce the silicate minerals enstatite, forsterite, diopside, and wollastonite, among several others, and addition of $\mathrm{H}_{2} \mathrm{O}$ introduces tremolite. Extension of these reactions to mantle pressures and higher temperatures produces significant solid solution in the pyroxene and carbonate minerals. The minerals produced by the decarbonation reactions include forsterite, orthopyroxene, and clinopyroxene. These are commonly used to model mantle processes in the system $\mathrm{CaO}-\mathrm{MgO}-\mathrm{SiO}_{2}$.

There are six decarbonation reactions at pressures above $10 \mathrm{~kb}$ that involve the mantle minerals. These are numbered in the direction of progressive decarbonation according to a scheme presented in detail elsewhere (Wyllie and Huang, in prep.).
Abbreviations for the minerals are explained in the legend to Figure 1, which illustrates reaction (6):
(1) $\mathrm{MC}+\mathrm{Qz} \rightleftharpoons \mathrm{En}+\mathrm{CO}_{2}$
(2) $\mathrm{Cm}+\mathrm{Qz} \rightleftharpoons \mathrm{Opx}+\mathrm{Cd}+\mathrm{CO}_{2}$
(3) $\mathrm{MC}+\mathrm{En} \rightleftharpoons \mathrm{Fo}+\mathrm{CO}_{2}$
(4) $\mathrm{Cm}+\mathrm{Opx} \rightleftharpoons \mathrm{Fo}+\mathrm{Cd}+\mathrm{CO}_{2}$
(5) $\mathrm{Cd}+\mathrm{Opx}+\mathrm{Qz} \rightleftharpoons \mathrm{Cpx}+\mathrm{CO}_{2}$
(6) $\mathrm{Cd}+\mathrm{Opx} \rightleftharpoons \mathrm{Cpx}+\mathrm{Fo}+\mathrm{CO}_{2}$

Maximum carbonation in the system is represented by the coexistence of quartz, carbonate, and $\mathrm{CO}_{2}$ (Fig. 1). With each decarbonation reaction, produced either by temperature increase or by pressure decrease, the surface connecting quartzcarbonates is broken by the appearance of a stability field involving one or more of the silicate minerals that are behind this surface, farther away from the $\mathrm{CO}_{2}$ apex of the tetrahedron. Figure 1 shows the compositions of pyroxenes Opx $+\mathrm{Cpx}$ and carbonates $\mathrm{Cm}+\mathrm{Cd}$ coexisting across solvi for a temperature of $1150^{\circ} \mathrm{C}$.

Reaction (1) breaks the join quartzmagnesite and replaces it with enstatite$\mathrm{CO}_{2}$, and reaction (2) is the equivalent quaternary reaction with solid solution in Opx and $\mathrm{Cm}$, which introduces dolomite solid solution, $\mathrm{Cd}$, across the carbonate solvus. Reaction (3) in the system $\mathrm{MgO}-\mathrm{SiO}_{2}-\mathrm{CO}_{2}$, determined by Newton and Sharp (1975), replaces the join enstatite-magnesite with forsterite- $\mathrm{CO}_{2}$, and reaction (4) is the equivalent quaternary reaction involving solid solutions Opx, $\mathrm{Cm}$, and $\mathrm{Cd}$. Reaction (5) uncovers the pyroxene solvus, exposing $\mathrm{Cpx}$ to $\mathrm{CO}_{2}$, and reaction (6) brings all three mantle minerals, Fo, Opx, and $\mathrm{Cpx}$, into coexistence with $\mathrm{CO}_{2}$ and a carbonate, $\mathrm{Cd}$, with composition between dolomite and calcite (Fig. 1). A similar reaction with a different carbonate was listed in an abstract by Eggler (1975). The reaction terminates at an invariant point near $25 \mathrm{~kb}, Q_{6}$, where the assemblage is joined by a liquid (Fig. 2).

Newton and Sharp (1975) determined the position of reaction (3). We have confirmed this and also located the position of reaction (6) (Fig. 2). At $15 \mathrm{~kb}$, reaction (3) occurs at $890^{\circ} \mathrm{C}$, reaction (6) at $960^{\circ} \mathrm{C}$, and both have a slope of $45 \mathrm{~b} /{ }^{\circ} \mathrm{C}$. Reaction (6) is thus situated within

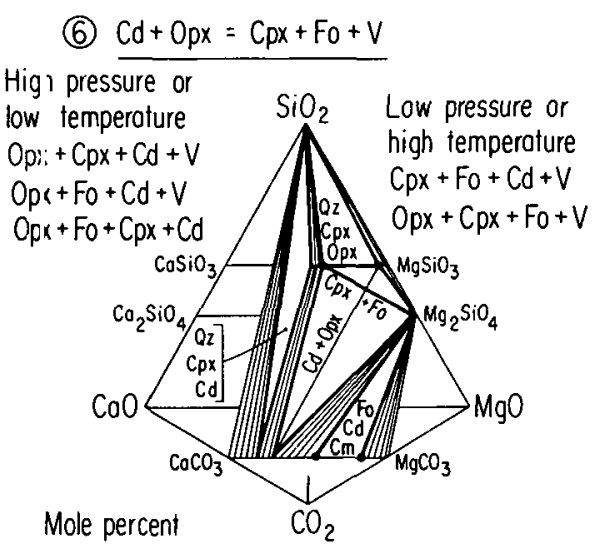

Figure 1. Isobaric isothermal diagram showing univariant decarbonation reaction (6), which involves mantle peridotite minerals olivine, orthopyroxene, and clinopyroxene. Phase fields shown are connected to $\mathrm{CO}_{2}$. At breviations: Fo, forsterite; Opx, orthopyroxene; $C_{p x}$, clinopyroxene; $Q z$, quartz or ot her silica polymorphs; $\mathrm{Cm}$, magnesite (MC) so.id solution; $\mathbf{C d}$, dolomite solid solution. $\mathrm{C}$ (mpositions of coexisting $\mathrm{Opx}$ and $\mathrm{Cpx}$ and of coexisting $\mathrm{Cm}$ and $\mathrm{Cd}$ are based on solvus curves by Nehru and Wyllie (1974) and Irving and Wyllie (1975).

$75^{\circ} \mathrm{C}$ and $3 \mathrm{~kb}$ of reaction (3), and reactions (4) and (5) occur within this ne.rrow band on the $P-T$ diagram.

\section{C.ARBONATION OF MANTLE PIERIDOTITE}

Reaction (3) represents carbonation of forsterite in the system $\mathrm{MgO}-\mathrm{SiO}_{2}-\mathrm{CO}_{2}$, w.rich provides an upper pressure limit for the existence of free $\mathrm{CO}_{2}$ in the mantle (Newton and Sharp, 1975). The peridotite carbonation reaction (6) illustrated in F gures 1 and 2 is situated about $3 \mathrm{~kb}$ lower than reaction (3). According to Ringwood's (1966) geotherms, Figure 2 confirms the conclusion of Newton and S.larp that free $\mathrm{CO}_{2}$ cannot exist in the r.antle except under conditions of unusually high temperature. Normally, $\mathrm{CO}_{2}$ would b: stored in the assemblage Fo + Opx $+\mathrm{Cpx}+\mathrm{Cd}$ (see Fig. 1).

All of the reactions (1) through (6) are displaced to lower temperatures in the presence of $\mathrm{CO}_{2}-\mathrm{H}_{2} \mathrm{O}$ mixtures (see Kerrick, 1974, for a review). Therefore, if an aqueous pore fluid exists in the 


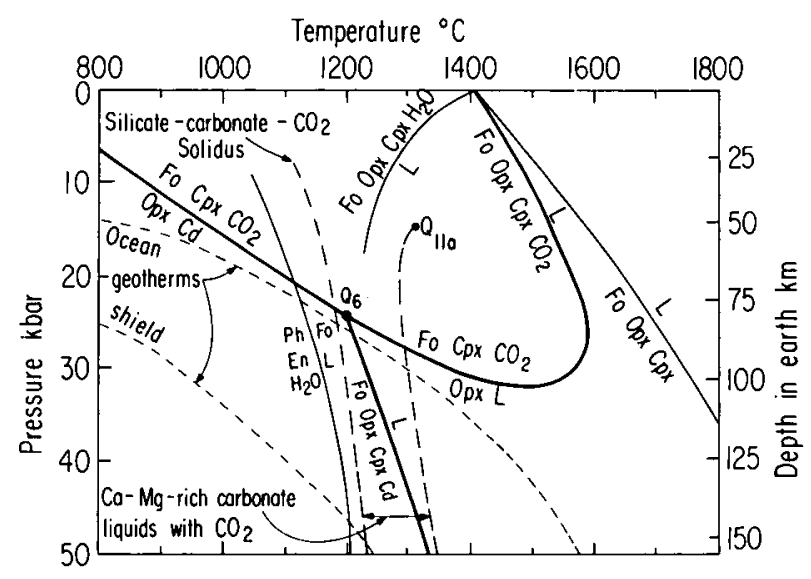

Figure 2. Univariant reactions for mantle peridotite assemblage Fo + Opx + Cpx with a small proportion of $\mathrm{CO}_{2}$ compared with other reactions. Subsolidus reaction (6) extending to invariant point $Q_{6}$ is illustrated in Figure 1. Abbreviations as in legend for Figure 1, with addition: $\mathrm{Ph}$, phlogopite.

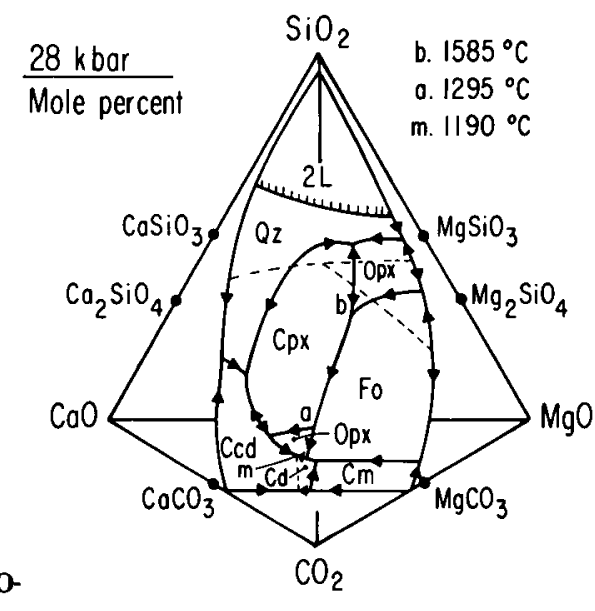

Figure 3. $\mathrm{CO}_{2}$-saturated liquidus surface in $\mathrm{CaO}-\mathrm{MgO}$ $\mathrm{SiO}_{2}-\mathrm{CO}_{2}$ at $28 \mathrm{~kb}$, partly

schematic. Abbreviations as in Figure 1, with additions: Ccd, carbonate solid solution between calcite and dolomite; $2 \mathrm{~L}$, two immiscible liquids.

upper mantle, $\mathrm{CO}_{2}$ could exist in the vapor phase along with partially carbonated peridotite. Addition of $\mathrm{H}_{2} \mathrm{O}$ to mantle peridotite would stabilize amphibole and phlogopite. The fusion curve for phlogopite coexisting with mantle minerals (Modreski and Boettcher, 1973) is shown in Figure 2. The position of this reaction and the stability of amphibole are changed in the presence of $\mathrm{H}_{2} \mathrm{O}-\mathrm{CO}_{2}$ vapors. Consideration of reactions such as these and the mineralogy of mantle samples might place limits on the possible ranges of $\mathrm{CO}_{2} / \mathrm{H}_{2} \mathrm{O}$ ratios in different depth intervals of the mantle.

\section{$\mathrm{CO}_{2}$-SATURATED LIQUIDUS-PHASE RELATIONSHIPS}

Each of the decarbonation reactions terminates at an invariant point where it reaches melting temperatures, with as assemblage involving liquid, $\mathrm{CO}_{2}$-vapor, carbonate minerals, and one of more of the silicate minerals Fo, Opx, Cpx, and Wo. The intersections of the decarbonation reactions with the solidus reactions in the system $\mathrm{CaO}-\mathrm{MgO}-\mathrm{SiO}_{2}-\mathrm{CO}_{2}$ produce an intricate series of liquidus reactions involving silicates and carbonates (Wyllie and Huang, in prep.). Figures 2 and 3 show some of these.

The melting relationships may be considered in two parts. Most investigators have been concerned with the hightemperature silicate-phase relationships in $\mathrm{CaO}-\mathrm{MgO}-\mathrm{SiO}_{2}$ - either volatile-free or with $\mathrm{H}_{2} \mathrm{O}$-and recently with $\mathrm{CO}_{2}$. We have been studying the carbonate melting relationships (Irving and Wyllie, 1975; Huang and Wyllie, 1975) and the liquidus relationships between carbonates and silicates (Huang and Wyllie, 1974; Maalфe and Wyllie, 1975). These involve a series of reactions at considerably lower temperatures than those for the silicate-rich part of the system. The links between these two parts are provided by the subsolidus decarbonation reactions (see Yoder, 1973; Eggler, 1975).

Figure 2 compares the solidus for the volatile-free peridotite assemblage with the melting curve produced by the solution of $\mathrm{CO}_{2}$. At $20 \mathrm{~kb}$, the melting temperature is lowered through $75^{\circ} \mathrm{C}$ by the solution of about 5 wt percent $\mathrm{CO}_{2}$ (Eggler, 1973, 1974). Our new data between 25 and $35 \mathrm{~kb}$ show the solidus in the presence of $\mathrm{CO}_{2}$ sweeping down through $400^{\circ} \mathrm{C}$ via a pressure maximum at about $32 \mathrm{~kb}$ and terminating at the invariant point $\mathrm{Q}_{6}$ near $25 \mathrm{~kb}$ and $1200^{\circ} \mathrm{C}$. Increase in pressure not only stabilizes carbonate in the subsolidus mineral assemblage, but also in the liquid phase, and this produces a large increase in $\mathrm{CO}_{2}$ solubility and the dramatic change in the reaction temperature. The solidus curve rising to higher pressures from $Q_{6}$ involves silicates and carbonates, without free $\mathrm{CO}_{2}$.

The $\mathrm{CO}_{2}$-saturated liquidus surface for $28 \mathrm{~kb}$ is illustrated in Figure 3. For compositions in the area $\mathrm{SiO}_{2}-\mathrm{CaSiO}_{3}$ $\mathrm{MgSiO}_{3}$, the $\mathrm{CO}_{2}$ solubility remains low, but for compositions ranging from the pyroxene join to the carbonate join, the $\mathrm{CO}_{2}$ content of liquids increases progressively to more than $45 \mathrm{wt}$ percent.

The dashed lines on the liquidus surface in Figure 3 show where the joins Wo-En- $\mathrm{CO}_{2}$ and Fo-Di- $\mathrm{CO}_{2}$ intersect it. At low pressures, the liquid $b$ lies within the dashed triangle, but Eggler (1974) showed that somewhere between 15 and $30 \mathrm{~kb}$ it crosses the join Fo-Di, becoming larnite-normative. Eggler reported a value of $1565^{\circ} \mathrm{C}$ for $b$ at $30 \mathrm{~kb}$, and this is used to plot the position of the melting reaction in Figure 2. Huang and Wyllie (1974) reported a liquidus-field boundary between Fo and $\mathrm{Cpx}$ extending down from $b$ toward the low-temperature carbonaterich liquids represented in Figure 3 by the liquidus minimum, $m$, whose position is controlled by the liquidus minimum in the carbonate join (Irving and Wyllie, 1975). This minimum, and related reactions at other pressures, is represented in Figure 2 by the dashed-line solidus at a temperature slightly below $Q_{6}$. The temperature interval for the existence of carbonate-rich liquids with compositions in the general area 
between $m$ and $a$ in Figure 3 is also indicated. The $\mathrm{CO}_{2}$-free solidus reaction rising to higher pressures from $Q_{6}$ in Figure 2 would be represented in Figure 3 by a point behind the liquidus surface, somewhat further away from the $\mathrm{CO}_{2}$ apex than liquids $m$ and $a$, but with similar high content of dissolved carbonates.

Figure 2 shows that at $28 \mathrm{~kb}$, the melting reaction for the assemblage $\mathrm{Fo}+\mathrm{Opx}+\mathrm{Cpx}+\mathrm{CO}_{2}$ is intersected twice, and the liquid compositions are represented in Figure 3 by the higher temperature liquid $b$ and the lower temperature liquid $a$ with much more dissolved $\mathrm{CO}_{2}$. With increasing pressure, points $b$ and $a$ approach each other, becoming coincident at $32 \mathrm{~kb}$ (Fig. 2). At higher pressures, the $\mathrm{CO}_{2}$-saturated liquidus fields for forsterite and clinopyroxene are separated by the field for orthopyroxene, and $\mathrm{CO}_{2}$-saturated liquids cannot exist in equilibrium with the peridotite assemblage.

\section{MAGMA GENERATION AND CRYSTALLIZATION}

Partial fusion of the peridotite assemblage produces forsterite-normative liquids that represent basalt, with compositions in the forsterite to pyroxene range. At $20 \mathrm{~kb}$, the melting temperature is lowered through more than $400^{\circ} \mathrm{C}$ by the solution of about 20 wt percent $\mathrm{H}_{2} \mathrm{O}$, as shown in Figure 2, and the liquid produced is quartz-normative (Kushiro, 1972). In contrast with $\mathrm{CO}_{2}$ the liquid is depleted in $\mathrm{SiO}_{2}$ (Fig. 3), becoming larnitenormative between $15 \mathrm{~kb}$ and $30 \mathrm{~kb}$ (Eggler, 1974). At $25 \mathrm{~kb}$ the solidus for peridotite with $\mathrm{CO}_{2}$ drops abruptly from $1575^{\circ} \mathrm{C}$ to $1200^{\circ} \mathrm{C}$ (at $Q_{6}$ ), and at higher pressures the first liquid produced is carbonatitic, with less than 10 wt percent dissolved silicates in liquid with composition near dolomite. Within the limited pressure interval corresponding to the depths from $80 \mathrm{~km}$ to $100 \mathrm{~km}$, there are remarkable changes in the compositions of liquids coexisting with peridotite mineral assemblages containing $\mathrm{CO}_{2}$; there are two liquids occurring at different temperatures, one representing kimberlite (b) and the other carbonatite (a).

These results indicate that partial fusion of mantle peridotite with $\mathrm{CO}_{2}$ at depths shallower than $80 \mathrm{~km}$ produces basaltic magmas, which become more undersaturated in silica with increasing depth. At depths greater than $80 \mathrm{~km}$, the first magmas produced in trace quantities (at much lower temperatures) are carbonatites. With progressive fusion, these are converted to kimberlite and eventually, at considerably higher temperatures, to basaltic magmas.

Crystallization of the high-temperature undersilicated basic magmas with dissolved $\mathrm{CO}_{2}$ yields residual kimberlite and carbonatite magmas. If these magmas fractionate without maintaining equilibrium with the host mantle peridotite, the residual liquids can reach the liquidus surface in Figure 3 and evolve $\mathrm{CO}_{2}$. The final carbonatite reach the dashed-line solidus in Figure 2, corresponding to the liquidus minimum $m$ in Figure 3 .

Carbonatite and kimberlite generated from mantle periodotite at depths greater than $100 \mathrm{~km}$ are undersaturated with $\mathrm{CO}_{2}$. Figure 2 shows that these magmas rising from the asthenosphere must evolve $\mathrm{CO}_{2}$ at a depth of 100 to $80 \mathrm{~km}$, which corresponds approximately to the lithosphereasthenosphere boundary. This would certainly contribute to their explosive eruption. The undersilicated basic magmas generated at higher temperatures do not have the same tendency to evolve $\mathrm{CO}_{2}$, except as a consequence of uprise to much shallower levels or of advanced crystallization.

In the presence of $\mathrm{CO}_{2}$ and $\mathrm{H}_{2} \mathrm{O}$, the phase relationships become more complex, and the possible processes of fusion and crystallization become more varied.

\section{SEISMIC LOW-VELOCITY ZONE}

One explanation for the seismic low-velocity zone is that traces of $\mathrm{H}_{2} \mathrm{O}$ in mantle peridotite cause incipient melting through the asthenosphere (Lambert and Wyllie, 1968). Green (1972) argued that the presence of $\mathrm{CO}_{2}$ bubbles in peridotite xenoliths transported from the asthenosphere in kimberlites or alkalic basalts indicated that the asthenosphere was dry and not partially melted.

Figure 2 shows that free $\mathrm{CO}_{2}$ cannot coexist in equilibrium with subsolidus mantle peridotite with normal temperature distributions. Apparently, the origin of $\mathrm{CO}_{2}$ bubbles in mantle xenoliths must be associated with relatively low temperature diapiric uprise or with relatively high temperature magmatic processes. In the depth range of the asthenosphere, $\mathrm{CO}_{2}$ appears to be as effective as $\mathrm{H}_{2} \mathrm{O}$ in causing incipient melting in mantle peridotite.

\section{REFIERENCES CITED}

Bow'en, N. L., 1940, Progressive metamorphism of siliceous limestone and dolomite: Jour. Geology, v. 48, p. 225-274.

Eggler, D. H., 1973, Role of $\mathrm{CO}_{2}$ in melting processes in the mantle: Carnegie Inst. Washington Year Book 72, p. 457-467.

- L $) 74$, Effect of $\mathrm{CO}_{2}$ on the melting of piridotite: Carnegie Inst. Washington Year Book 73, p. 21 5-224.

- 1775 , Carbonate generation by a reaction relation in the system CaO-MgO-SiO 2 $\mathrm{CO}_{2}$ at $30 \mathrm{kbar}$ pressure: $\mathrm{EOS}$ (Am. (eophys. Union Trans.), v. 56, p. 470.

Green, H. W:- -1972, $\mathrm{A} \mathrm{CO}_{2}$-charged asthenos. ohere: Nature, v. 238, p. 2-5.

Huang, W. L., and Wyllie, P. J., 1974 , Futectic between wollastonite II and calcite contrasted with thermal barrier ill $\mathrm{MgO}-\mathrm{SiO}_{2}-\mathrm{CO}_{2}$ at 30 kilobars, with applications to kimberlite-carbonat ite fetrogenesis: Earth and Planetary Sci. l,etters, v. 24, p. 305-310.

- 1975, Melting relationships in the systems ( $\mathrm{aO}-\mathrm{CO}_{2}$ and $\mathrm{MgO}-\mathrm{CO}_{2}$ to 33 kilobars: (jeochim. et Cosmochim. Acta (in press).

Irving, A. J., and Wyllie, P. J., 1975, Subsolidus and melting relationships for :alcite, magnesite and the join $\mathrm{CaCO}_{3}$. $\mathrm{MgCO}_{3}$ to $36 \mathrm{~kb}$ : Geochim. et Cosmochim. Acta, v. 39, p. 35-53.

Ker:ick, D. M., 1974, Review of metamorphic inixed-volatile $\left(\mathrm{H}_{2} \mathrm{O}-\mathrm{CO}_{2}\right)$ equilibria: Am. Mineralogist, v. 59, p. 729-762.

Kushiro, I., 1972, Effect of water on the :omposition of magmas formed at high jressures: Jour. Petrology, v. 13, p. 311-334.

Lambert, I. B., and Wyllie, P. J., 1968 , Stability of hornblende and a model for the low velocity zone: Nature, v. 219 , p. 1240-1231.

Masl $\phi$ e, S., and Wyllie, P. J., 1975, The join grossularite-calcite through the system $\mathrm{CaO}-\mathrm{Al}_{2} \mathrm{O}_{3}-\mathrm{SiO}_{2}-\mathrm{CO}_{2}$ at 30 kilobars: Crystallization range of silicates and carbonates on the liquidus: Earth and Planetary Sci. Letters (in press).

Modreski, P. J., and Boettcher, A. L., 1973, Phase relationships of phlogopite in the system $\mathrm{K}_{2} \mathrm{O}-\mathrm{MgO}-\mathrm{CaO}-\mathrm{Al}_{2} \mathrm{O}_{3}-\mathrm{SiO}_{2}-\mathrm{H}_{2} \mathrm{O}$ to 35 kilobars: A better model for micas in the interior of the earth: Am. Jour. Sci., v. 273 , p. $385-414$.

Nehru, C. E., and Wyllie, P. J., 1974, Electron microprobe measurement of pyroxenes coexisting with $\mathrm{H}_{2} \mathrm{O}$-undersaturated liquid in the join $\mathrm{CaMgSi}_{2} \mathrm{O}_{6}-\mathrm{Mg}_{2} \mathrm{Si}_{2} \mathrm{O}_{6}-\mathrm{H}_{2} \mathrm{O}$ at 30 kilobars, with applications to geothermometry: Contr. Mineralogy and Petrology, v. 48, p. 221-228.

Newton, R. C., and Sharp, W. E., 1975 , Stability of forsterite $+\mathrm{CO}_{2}$ and its bearing on the role of $\mathrm{CO}_{2}$ in the mantle: Earth and Planetary Sci. Letters (in press).

Ringwood, A. E., 1966, Mineralogy of the mantle, in Hurley, P. M., ed., Advances in Earth science: Cambridge, Mass., M.I.T. Press, p. 357-399.

Yoder, H.S., Jr., 1973, Akermanite- $\mathrm{CO}_{2}$ : Relationship of melitite-bearing rocks to kimberlite: Carnegie Inst. Washington Year Book 72, p. 449-457.

\section{ACKNOWLEDGMENTS}

Reviewed by A. T. Anderson and J. R.

Goldsmith.

Supported by National Science Foundation Grant GA-41730, and by the Materials Research Laboratory of the National Science Foundation.

NIANUSCRIPT RECEIVED JULY 3, 1975

MANUSCRIPT ACCEPTED AUG. 12, 1975 